\title{
Role of Notary in Capital Market: Making GMS Minutes Online During Covid-19
}

\author{
Rais Firdaus Handoko*) and Budi Santosa*)
}

*) Students of Master of Notarial Law, Universitas Diponegoro, Email: raisfirdaus@gmail.com

**) Lecturer of Faculty of Law, Universitas Diponegoro, Email:

budisantosa@gmail.com

\begin{abstract}
In early 2020, the world was shocked by the rapid spread of the novel coronavirus disease known as the corona virus disease which came out at the end of 2019 (COVID-19), so that the whole world took many policies with online system, including lectures and notary activities. The purpose of this paper is to explain controversy over the principle of lex specialis derogate legi generalis in the capital market notary and legality of making the deed of the minutes of the GMS online by a capital market notary can provide justice for notaries. This research used a normative juridical research with the specification of the research was carried out descriptively and analytically. Normative research uses secondary data types. The data collection method used by conducting Library Research and the techniques used in describing and processing the collected data are qualitative descriptions. This writing can be concluded that the deed of the minutes of the GMS of capital market companies in accordance with Article 5 paragraph (1) of the Electronic Information and Transaction Law includes the so-called electronic documents which are valid evidence, while in Article 16 letter $m$ of the Law on Notary Position, it is stated in the explanation of this Article. "That the notary must be physically present and sign the deed before the audience and witnesses". The author's suggestion is to revise the Law on the Position of Notary Public, legalize the formation of GMS minutes online both during the corona virus pandemic and after the end of the virus, so that these rules can adapt to the needs of today's life which are completely electronic, internet, digitization, and computerized.
\end{abstract}

Keywords: Regulations Conflict; Minutes of GMS; Electronics; Digitalization.

\section{INTRODUCTION}

According to the author, law is a rule formed by the government (law making institution) as an implementation of the sovereignty that has been given by the people (sovereignty) which forces it to be obeyed (imperative) because there is a threat of sanctions if it is violated. The formation of law aims to create justice and peace in life (in peace there is prosperity, order and justice) in society. When forming a law, it is obligatory to explore the values and norms in society. If this can be achieved, so-called responsive law will be achieved, namely law that is in accordance with the wishes and substance of society, so that law is created for humans, it is necessary to accommodate human needs, not humans are created to submit to the law. 
As stated in the principle of legality by Lonn Fuller, that the law must be published, the law must not be changed too often, etc. so that there is also one important principle that the formation of law must be adjusted to the needs of everyday society. So that the development of life becomes an era of digitalization (everything is completely online), resulting in the law must be able to adapt in formulating its norms according to the rules that can accommodate online.

Written in Article 16 letter m Law of Notary Position Number 2 of 2014 reads, "read out the deed in front of the audience in the presence of at least 2 (two) witnesses, or 4 (four) special witnesses for the making of the will under hand, and signed on the spot by the tappers, witnesses, and notary ", in the explanation of the Article strengthens it with the sound" that the notary must be physically present and sign the deed in the presence of the audience and witnesses ", from here the author interprets that everything regarding the agreement deed agreement, must be a notary and the parties are physically present ${ }^{1}$.

Instantly at the beginning of 2020, the world was shocked by the rapid spread of the novel coronavirus disease known as the corona virus disease which came out at the end of 2019 (COVID-19), then a few months after the initial arrival of the corona virus in December 2019 in the territory of China, it spread with fast, until around February, the World Health Organization (WHO) announced the death of the disease so that a pandemic policy was issued, so that activities were disrupted and limited by physical distinctions (distance) so that the disease was not transmitted to other people, so the whole world took many policies with an online system, including lectures and notary activities.

On the one hand, the Law on Notary Office opposes not meeting, but the author finds that the Law on Information and Electronic Transactions that will be explained in the sub-discussion allows (legalizes) the agreement of non-physical agreements through online. Here the authors identify the problem that leads to a contradiction in the legal principles of lex specialis derogate legi generalis (the legal umbrella should be obeyed more than general law).

\section{METHODS}

Research is an important thing for the development of science and technology. The method applied must be in accordance with the parent science. But that does not mean that the methodology of each science is completely different. Although different, these studies have the same goal, namely to reveal the truth systematically and consistently. ${ }^{2}$ The technique used in describing and processing the collected data is a qualitative description. Qualitative descriptions are used in the method of describing the data in this study because the main data used are not numbers that can be measured. According to Ronny Hanitijo Soemitro, normative legal research emphasizes

\footnotetext{
${ }^{1}$ Adigita, Monicha R., Ma'ruf, Umar., \& Witasari, Aryani. (2019). The Role and Protection of Laws to Notary Related To the Dispute That Made Between the Parties. JURNAL AKTA: Vol. 6, No. 4, 783-788. Retrieved from http://jurnal.unissula.ac.id/index.php/akta/article/view/7631 ${ }^{2}$ Soekanto, Soerjono \& Sri Mamudji. (2013). Penelitian Normatif. Jakarta: Rajagrafindo Persada, p. 1.
} 
speculative-theoretical steps and normative-qualitative analysis. ${ }^{3}$ The entire data that is edited and processed, is analyzed by qualitative methods, meaning that it is not merely aimed at expressing the truth, but understanding the truth. Then a conclusion is obtained that can answer the existing problems.

\section{RESULTS AND DISCUSSION}

\subsection{Ideal Law Review}

Law is one of the disciplines that has an interdisciplinary nature. Interdisciplinary is that the science of law helps to explain problems related to society, it can also be said that law science is a prescriptive science (science that provides instructions for evaluating and behaving as suggested by Zevenbergen, 1925: 110 - 124).

In this sub-chapter the author wants to explain das sollen (legal theory that should be) as a guide so that notaries in Indonesia can realize a sense of justice and welfare because public officials who are not paid by the Indonesian government, but whose movements are mostly restricted by the State, so we must first understand. In the past, theories related to capital market notaries could get justice and be in accordance with today's digitalized and electronic era.

Talking about the ideal legal review, the author will use three theories as a knife to analyze this journal's writing, namely:

a. Gustav Radbruch: Three Basic Values of the Law. That law must include three basic values, especially justice, because it is the root for creating world welfare and order. The three basic values are the value of Justice, usefulness/benefit, and legal certainty. The essence of law is to create substantial justice, create justice by formalizing the law (the value of legal certainty) because it will give rise to legal force, have formal sanctions, and ipsojure. But the value of legal certainty can only be applied if the formation of the law is in accordance with what is needed in society (the value of benefit), then justice will be created. ${ }^{4}$

b. Jeremy Bentham: Utilitarialime. The point is that laws are formed to achieve a specific goal, namely happiness. But the measure of legal happiness is to serve the greatest happiness of the greatest number of people, so that it only agrees with the majority and can remove the rights of minorities, the most important thing is that the greatest happiness in a society has been achieved. ${ }^{5}$

c. Legal Principles: Lex specialis deroget legi generalis. The law that must be obeyed, especially the regulations, especially if the institution is authorized to form these regulations, which ultimately overrides the general rules/guidelines. For example, as in the covid-19 case, making the President the institution authorized to form a Perppu, Perppu regulation No. 2 of 2020 can temporarily override the Election Act No. 7 of 2017 until the Perppu is discussed in a plenary

\footnotetext{
${ }^{3}$ Ibid.

${ }^{4}$ Understanding the author's scientific summary.

5 Prasetyo, Teguh \& Abdul Halim Barkatullah. (2011). Law Science \& Legal Philosophy. Yogyakarta: Pustaka Pelajar, p. 60.
} 
meeting of the House of Representatives (DPR) whether in the future it will become an official law or not, if it does not take effect temporarily until the DPR holds a meeting to discuss the laws and regulations in the State of Indonesia. ${ }^{6}$

\subsection{About Covid-19}

On December 31, 2019, the WHO China Country Office reported a case of pneumonia in Wuhan City, Hubei Province, China. On January 7, 2020, China identified pneumonia of unknown etiology as a new type, namely coronavirus (novel coronavirus). In early 2020 the NCP began to become a global pandemic and became a health problem in several countries outside the PRC. According to the World Health Organization (WHO), pneumonia cluster cases with unclear etiology in Wuhan City have become health problems around the world. The spread of this epidemic continued to grow until it was finally known that the cause of this pneumonia cluster was the Novel Coronavirus. This pandemic continues to grow until there are reports of deaths and new cases outside China. On January 30, 20207. On February 12, 2020, WHO officially designated the novel coronavirus disease in humans as Coronavirus Disease (COVID-19). COVID-19 is caused by SARS-COV2 which belongs to the same large family of coronaviruses that caused SARS in 2003, only with different types of virus. Symptoms are similar to SARS, but the SARS mortality rate $(9.6 \%)$ is higher than COVID-19 (currently less than $5 \%$ ), although the number of COVID-19 cases is far more than SARS. COVID-19 also has a wider and faster spread to several countries than SARS.

\subsection{Controversy over the Principle of Lex Specialis Derogate Legi Generalis}

It has been slightly touched on by the author above in the introductory sub-section, that the rules in the Law on Notary Office really do not make it easier for notaries to approve agreements when during the pandemic of this corona virus, because they still do not allow online while in the Limited Liability Company Law and the Law on Information and Electronic Transactions already allow online, even though when they need a notary, of course they (companies, companies, and other legal subjects) will obey the rules of the Notary Position, this is considered by the author of the conflict of the special law (Law on Notary Position) with the general law (Limited Liability Company Law and Law Electronic Information and Transactions) ${ }^{8}$.

The author states that it is written in Article 16 letter m Act of Notary Position Number 2 of 2014 which reads, "read out the deed in front of the audience in the presence of at least 2 (two) witnesses, or 4 (four) special witnesses. for making a will under hand,

\footnotetext{
${ }^{6}$ Ibid.

7 "Coronavirus Disease 2019 (COVID-19)", Centers for Disease Control and Prevention (CDC). February 15, 2020. Archieved from the original on 26 February 2020. Retrieved 20 February 2020, quoted from the Ministry of Home Affairs Work Team for the Support of the COVID-19 Task Force, General Guidelines for Facing the COVID-19 Pandemic for Local Governments (Prevention, Control, Diagnosis, and Management). (Jakarta: Ministry of Home Affairs, 2020), p. 7.

8 Ferdiyanti, M. Indah Verena., Purnawan, Amin., \& Soegiyanto. (2019). Setting the Effectiveness of Law Position and Code Notary to the Quality of Performance. JURNAL AKTA: Vol. 6, No. 4, 797-804. Retrieved from http://jurnal.unissula.ac.id/index.php/akta/article/view/7887
} 
and signed on the spot by the tappers, witnesses, and notary public ", in the explanation of the Article strengthens it by saying" that the notary must be physically present and sign the deed before the tappers and witnesses ", from here the author interprets that everything regarding the agreement agreement deed, must be a notary and the parties are physically present.

Whereas regarding the deed of the minutes of the GMS, it is not required to be rewritten by a Notary for legality (legally), but Article 90 of Act No. 40 of 2007 concerning Limited Liability Companies reads, "every time a GMS is held, the minutes of the GMS must be drawn up and signed by the chairman of the meeting and at least 1 (one) shareholder appointed from and by the GMS participants. The signature as referred to in paragraph 1 (one) is not required if the minutes of the GMS are made with a notarial deed".

This is then related to even though Article 5 paragraph (1) of Act No. 11 of 2008 concerning Electronic Information and Transactions states, "electronic information and/or electronic documents and/or their printouts are valid legal evidence", indeed the rules of Article 5 paragraph (1) there is an exception as referred to in Article 5 paragraph (4) which reads, "The provisions regarding electronic information and/or electronic documents as referred to in paragraph (1) do not apply to: a. a letter which according to the law must be in writing; and b. a letter and its documents which according to the law must be made in the form of a notarial deed or a deed established by the official who made the deed ".

But because Article 90 of the Limited Liability Company Law above states that the treaty deed of RPUS is not required (required) to be made with a notary deed, it means that in this case there is freedom by capital market companies if they want to request a notary's assistance to further strengthen the proof of the minutes of the GMS or not to ask notary assistance. So that the authors interpret because of this freedom means that it does not include the absolute authority of the notary (because there is an option "not required"), this means that according to the author it cannot be linked to Article 5 paragraph (4) of the Information and Electronic Transaction Law, because in that Article refers to the word "Which according to the law must be made in the form of a notarial deed", whereas in Article 90 of the Limited Liability Company Law it is called "not required".

The author interprets to mean the deed of the minutes of the GMS of capital market companies in accordance with Article 5 paragraph (1) of the Law on Electronic Information and Transactions, including so-called electronic documents which are valid evidence. So that it is clear that the general law/lex generalis (Limited Liability Company Law) does not designate/require the minutes of the GMS to be made by a Notary as Article 90, so that it is not included in groups that according to law must be made in the form of deeds, so that it is not a notarial deed but an electronic document which is a valid evidence.

Whereas the meaning of electronic documents according to Article 1 point 4 of the Electronic Information and Transactions Law states, "electronic documents are any electronic information created, forwarded, sent, received, or stored in analog, digital, electromagnetic, optical, or the like, which can be seen. displayed, and/or heard 
through a computer or electronic system, including but not limited to writing, sound, pictures, maps, designs, photographs, or the like, letters, signs, numbers, access codes, symbols or perforations that have meaning or meaning or it can be understood by someone who can understand it ". This is what the author means contrary to Article 16 letter $m$ of the Law on the Position of Notary Public (its lex specialis),

In law we recognize the principle of lex specialis deroget legi generalis, which means that if there is a special regulation regulating the object, it will set aside the general rule, from here it means that the Law on Notary Position is a special regulation which regulates more deeply the roles, obligations, powers, as well as the prohibition made by a Notary, then overriding the Limited Liability Company Law and the Electronic Information and Transaction Law, but the intention of ignoring the priority of its application, means that legal subjects wishing to use a notary must acknowledge and comply with the Law on Notary Position, especially if they want to ask a notary for help in making deed and agreement agreement. Even though there is a contradiction here, namely the lex specialis the Law on Notary Position prohibits online and physical meetings

Also, if the theory of justice described by the writer above is to be applied, it still cannot reflect justice, both the theory of Gustav Radbruch's three basic values, Jeremy Bentham's utilitarianism, and the legal principles of lex specialis derogate legi generalis.

\subsection{Legality of Making GMS Minutes Deed online by Capital Market Notary the Just}

This shows clearly that rule makers are people who do not understand and are careless in making regulations regarding the Position of Notary Public. Before making regulations, it should be studied and studied as best as possible and as accurately as possible, if necessary, deepen the reading and history of the notary office if necessary. So that in the future the revision of the Law on the Position of Notary Public can be useful for Notaries as the theory of utilitarianism which emphasizes benefit before legal certainty so that if it is deemed useful the legal rules to be made for Notaries and according to everyday people's life (sub in the principle of legality), then write it down in the Article norm of the revision of the Law on the Position of Notary Public.

Notary profession is a public office that has a high philosophy, namely "upholding dignity, dignity and honor". Do not let this philosophical understanding be tampered with and dissolved by the government and the state in the meaning of an unfair system, namely the absence of a balance of rights and obligations, resulting in the notary's position in the realm of government (state) to be overlapping and unclear, in fact where the state wants to place Notary, which in the end will create confusion and make it difficult for the Notary in a difficult and biased future, especially in making ends meet ${ }^{9}$.

\footnotetext{
9 Deen, Thaufiq., Ong Argo Victoria \& Sumain. (2018). Public Notary Services In Malaysia. JURNAL AKTA: Vol. 5, No. 4, 1017-1026. Retrieved from http://jurnal.unissula.ac.id/index.php/akta/article/view/4135
} 
The concept of a welfare state should place citizens or individuals into legal subjects that must be protected and prosperous in all aspects of their lives. The State regulates both public and private matters, which emphasizes regulating relations between individuals in Civil Law, especially the State also needs to pay attention to the welfare of Notaries who have helped facilitate the work of State Land Agency agreements as representatives of the State.

Notary is a party who helps the community for and on the duties of the authority of the state. Making an authentic deed with all the risks and responsibilities that are not light. If there is a writing error in the substance of the deed, the Notary may be affected by public reporting to the court. People who need ties through deeds as their protectors in acting in order to achieve planned goals.

The role of the notary in this matter from time to time is actually not in doubt. Thanks to the notary's performance, economic traffic, especially with regard to agreements, engagements, inheritance, and others, legal actions by people who need them and take legal actions are helped in proving authentic deeds, so that they get legal certainty. The government should be grateful to the Notary who has helped them bridge the legal actions of the community privately regarding agreements and commitments to the National Land Agency (as the government), it should provide more legal certainty to Notaries in order to get a more decent and prosperous life and justice, because if in The regulations alone are ambiguous and biased, how can the future of the Notary be better in the future ${ }^{10}$.

Because the history of the Notary from its inception to Indonesia needs to be reviewed by the government and the state. Notaries are known not only as writers, "stamps" and deeds maker. But more than that, many of them are people of the movement, intellectuals, who have been shown to influence the dynamics of changing world. ${ }^{11}$

So that according to the author, both the Limited Liability Company Law and the Information and Electronic Transaction Law already reflect the rules that are tailored to the needs of the current daily life of society by legalizing online documents, so that the rules of the Law on Notary Position really need to be changed as long explanation above that how much The Position of Notary is valuable so that the making of the rules for the Position of Notary Public must be made seriously and not playing games so that there are no longer conflicts between other notary regulations.

\section{CLOSING}

The author interprets to mean the deed of the minutes of the GMS of capital market companies in accordance with Article 5 paragraph (1) of the Law on Information and

\footnotetext{
${ }^{10}$ Rachmawati, Noor., \& Hanim, Lathifah. (2018). Notary Role in The Establishment of Foreign Investment Limited Company Based on The Act No. 25 Of 2007 on Investment in Semarang. JURNAL AKTA: Vol. 5, No. 4, 965-974. Retrieved from http://jurnal.unissula.ac.id/index.php/akta/article/view/3939

11 Study of Public Information, Notary-PPAT Continues to be enslaved by the State and Government.

Adapted fromhttps://www.hukumonline.com/berita/baca/lt4cb2f59733dd2/notaris-pejabat-umum-yangbukanpejabat-negara/ November 26, 2019 at 09:04 WIB
} 
Electronic Transactions, including so-called electronic documents which are valid evidence. So, it is clear that the general law/lex generalis (Limited Liability Company Law) does not designate/require the minutes of the GMS to be drawn up by a Notary as Article 90, so that it is not included in groups that according to law must be made in the form of deeds. So that it is not a notarial deed but an electronic document which is valid evidence. This is what the author means contradicting Article 16 letter $\mathrm{m}$ of the Law on the Position of Notary Public (its lex specialis), because it is stated in the explanation of the Article "that notaries must be physically present and sign the deed in front of witnesses and witnesses", this is clear because of the corona virus which requires maintaining distance and restrictions on meeting (social distancting and physical distancting) whatever must be done remotely, especially the notary making of trial minutes, the impact must be done online, even though the lex specialis Law in the Law on Notary Position does not allow this.

\section{References}

Journals:

Adigita, Monicha R., Ma'ruf, Umar., \& Witasari, Aryani. (2019). The Role and Protection of Laws to Notary Related To the Dispute That Made Between the Parties. JURNAL AKTA: Vol. 6, No. 4, 783-788. Retrieved from http://jurnal.unissula.ac.id/index.php/akta/article/view/7631

Deen, Thaufiq., Ong Argo Victoria \& Sumain. (2018). Public Notary Services In Malaysia. JURNAL AKTA: Vol. 5, No. 4, 1017-1026. Retrieved from http://jurnal.unissula.ac.id/index.php/akta/article/view/4135

Ferdiyanti, M. Indah Verena., Purnawan, Amin., \& Soegiyanto. (2019). Setting the Effectiveness of Law Position and Code Notary to the Quality of Performance. JURNAL AKTA: Vol. 6, No. 4, 797-804. Retrieved from http://jurnal.unissula.ac.id/index.php/akta/article/view/7887

Rachmawati, Noor., \& Hanim, Lathifah. (2018). Notary Role in The Establishment of Foreign Investment Limited Company Based on The Act No. 25 Of 2007 on Investment in Semarang. JURNAL AKTA: Vol. 5, No. 4, 965-974. Retrieved from http://jurnal.unissula.ac.id/index.php/akta/article/view/3939

Books:

Prasetyo, Teguh \& Abdul Halim Barkatullah. (2011). Law Science \& Legal Philosophy. Yogyakarta: Pustaka Pelajar

Soekanto, Soerjono \& Sri Mamudji. (2013). Penelitian Normatif. Jakarta: Rajagrafindo Persada

\section{Regulations:}

Act No. 2 of 2014 concerning Amendments to Act No. 30 of 2004 concerning the Position of Notary Public.

Act No. 40 of 2007 concerning Limited Liability Companies.

Act No. 11 of 2008 concerning Electronic Information and Transactions. 


\section{JURNAL AKTA}

eISSN : 2581-2114, pISSN: 2406-9426

Internet:

Public Information Studies, PPAT Notaries Continue to be enslaved by the State and Government, in https://kajianinformasipublik.com/notaris-ppat-terusdiperbudak-negara-dan-pemerintah accessed on Tuesday, November 26, 2019 